\section{Franc Križnar}

Univerza v Mariboru
DOI: https://doi.org/10.18485/slovenika.2019.5.1.7

UDK: 78(497.11:497.4)«18/20«

Centar za interdisciplinarne in

multidisciplinarne raziskave in študije

Inštitut glasbenoinformacijskih znanosti

Slovenija

franc.kriznar@siol.net

\title{
Slovensko srbski kulturni in še posebej glasbeni odnosi Glasba je brezmejna!
}

Glasbena umetnost je več kot univerzalna, zato so dandanes na tej relaciji le še državne meje, ki pa jih stoletja nazaj sploh ni bilo. Morda pa so zato $\checkmark$ ospredju specifični samo še nacionalni (ljudski) elementi in pa dandanašnji aktualni (glasbeni) modernizem.

\section{Povzetek}

Glasbeni odnosi med Slovenijo in Srbijo so skozi več kot 200-letni razvoj ostali bogati in raznoliki. Dolgo sta jih pogojevali skupna politična situacija in država (Avstroogrska monarhija, Država SHS, Kraljevina Jugoslavija, FLRJ in SFRJ). Med obema vojnama in zlasti še po 2. svetovni vojni je bilo medsebojno sodelovanje intenzivno, vendar je kasneje, po letu 1991, razvodenelo $v$ naključja in posamičnosti, četudi neke vrste sodelovanje obstaja še dandanes, predvsem na ravni bilaterale, tj. dvostranskosti. $V$ preteklosti pa je obstajal dokaj enovit slovanski nacionalni prostor, $v$ katerem $z$ vidika ustvarjalnosti ne moremo spregledati Davorina Jenka. Bil je tisti vezni člen med Slovenijo in Srbijo, ki drži še dandanes: ustvarjalno, poustvarjalno in pedagoško. Med množico gostujočih skladateljev, ustvarjalcev in poustvarjalcev (izvajalcev), pevk in pevcev, dirigentov in instrumentalistov, tako Slovencev kot Srbov, ne morem niti mimo Mihovila Logarja, Marjana Kozine in Zlatana Vaude. Pričujoča obravnava bogate mednarodne izmenjave zajema tudi balet. Gre za povsem drugačno in raznoliko sodelovanje, ki ga je dandanes vse manj: sodelovanje na področju (glasbene) umetnosti, pedagogike in znanosti.

Ključne besede: bilaterala, Jenko, Logar, Kozina, Vauda 


\section{Uvod}

Slovenija je evropska država z zemljepisno lego na skrajnem severu Sredozemlja in na skrajnem jugu Srednje Evrope. Na zahodu meji z Italijo, na severu z Avstrijo, na severovzhodu z Madžarsko in na vzhodu in jugu s Hrvaško. Leži na stičišču alpskega, sredozemskega, panonskega in dinarskega sveta. S Srbijo pa jo druži kar nekaj desetletno (1918-1991) skupno državništvo: Država Srbov Hrvatov in Slovencev, Kraljevina Jugoslavija in FLRJ-SFRJ. Republika Srbija pa je celinska država, ki leži na Balkanskem polotoku, v jugovzhodni in deloma v srednji Evropi.

Med »univerzalnimi« ali celo evropeiziranimi, tako srbskimi kot slovenskimi (glasbenimi) avtorji-ustvarjalci-skladatelji v nekaj več kot 200-letnem zgodovinskem in še posebej glasbenem razvoju uvodoma ne smemo in ne moremo spregledati takih, kot so npr. med Srbi: Kornelije Stanković, Davorin Jenko, Josif Marinković, Stevan Stojanović Mokranjac, Stanislav Binički, Petar Stojanović, Isidor Bajić, Petar Konjović, Miloje Milojević, Stevan in Zoran Hristić, Milenko Paunović, Kosta Manojlović, Jovan Bandur, Mihajlo Vukdragović, Vlado in Predrag Milošević, Marko Tajčević, Milenko Živković, Svetomir Nastasijević, Mihovil Logar, Dragutin Čolić, Milan Ristić, Ljubica Marić, Vojislav Vučković, Stanojlo Rajičić, Milutin Radenković, Enriko Josif, Vlastimir Peričić, Aleksandar Obradović, Dušan Radić idr.; ter med Slovenci: Jakob Gallus, Risto Savin (Friderik Širca), Gojmir (Gregor) Krek, Emil Adamič, Anton Lajovic, Slavko Osterc, Marij Kogoj, Karol Pahor, Matija Bravničar, Lucijan Marija Škerjanc, Blaž Arnič, Danilo Švara, Marjan Kozina, Pavel Šivic, Marijan Lipovšek, Primož Ramovš, Zvonimir Ciglič, Uroš Krek, Janez Matičič idr. (Jugoslovenska umetnost 1972, 231-33). Eni in drugi pa še marsikdo od ostalih so bili redno in so še danes prisotni na pultih izvajalcev obeh narodov. Oboji so del evropskega in svetovnega (glasbenega) repertoarja, kar pa še najbolj depolarizira njihovo morebitno nacionalno opredelitev. Čeprav je večina obeh nacionalnih predstavnikov še najbolj značilna $v$ nacionalnem ali več nacionalnih pogledih, je njihova »dodana « vrednost prav v tem, da so eni in drugi (več kot) univerzalni za obe naciji, naroda. Med njimi pa najdemo tudi take, ki so za časa svojega življenja še dodatno oplajali oba naroda tako z neposrednim delovanjem na obeh prostorih kot tudi in predvsem s svojo avtorsko, skladateljsko zapuščino, opusom tu in tam, torej v Sloveniji in Srbiji.

Posebno področje enega in drugega, torej slovenskega in srbskega (glasbenega) prostora je tudi ljudska glasba. Posebej jo preučuje etnomuzikologija, tj. interdisciplinarna znanstvena veda, ki ima $v$ obeh državah svoj najvišji akademski rang, tako na znanstveni in raziskovalni ravni obeh Akademij $^{1}$ kot na pedagoško raziskovalni ravnini univerzitetnega študija. Povsod pa so seveda spet v ospredju tipični ljudski pevci in plesalci, solisti in ansambli, nekje tudi profesionalno (Beo-

${ }^{1}$ Akademije znanosti in umetnosti v Ljubljani in Srpske akademije nauka i umetnosti u Beogradu. 
grad), spet drugje amatersko, ljubiteljsko (Ljubljana). Za obe nacionalni vrsti ljudske glasbe (slovenske in srbske) je značilna tako balkanska kot evropska orientacija. Njeni »podkasti« so še: etno- popularna, popularno-etno, zabavna idr. Za obe je značilno tudi izročilo kot značilna raznolikost, ki so jo v preteklosti ustvarili različni vplivi kot posledico geografske lege ozemlja in zgodovinskih dogajanj. Predvsem na obmejnih območjih je ves čas prihajalo do medsebojnega vplivanja različnih etnij, kar se odraža tako $v$ vokalni kot tudi inštrumentalni glasbi.Značaj glasbe je po pokrajinah sicer različen, osnovne značilnosti večjega dela ljudskega glasbenega izročila pa imajo tudi skupne lastnosti: pretežno diatonična glasba, parni - večinoma dvo- in tridobni plesi oz. različice polk in valčkov. Manjše godčevske zasedbe so pravilo, $v$ uporabi so bila zelo različna glasbila, vodilno vlogo je nekoč poleg pihal imela violina, pozneje jo je izpodrinila diatonična harmonika (Rauch 2016, 87) - Avseniki in nadaljevalci v Sloveniji. Srbske folklorne pesmi, ljudske in tradicionalne pesmi (pesništvo), ki dandanes kulminirajo vsaj v primeru s Svetlano Spajić (Srbija). Tako kot so za Slovenijo novodobni sinonim narodno zabavne glasbe Avseniki ${ }^{2}$ in diatonična harmonika (frajtonarica) $)^{3}$, so za Srbijo Guča ${ }^{4}$ in gusle. ${ }^{5}$

Vloga ljudske glasbe se je $v$ sodobnosti močno spremenila, posledično pa tudi oblika, predvsem pod vplivom medijev. Tu in tam so $\mathrm{v}$ ospredju pevski zbori in folklorni ansambli. Zanimivo je še aktualno oplajanje enega in drugega nacionalnega prostora: da Slovenci v Srbiji in Srbi v Sloveniji zaradi maksimalnega in enovitega toleriranja obeh nacij pomenijo tudi tovrstne srbske dosežke $v$ Sloveniji in slovenske $v$ Srbiji. To pa so že rezultati, ki jih dosegajo današnje najsodobnejše komunikacije in tolerance. Te obstajajo na obeh ravneh, državniško (omenimo lahko tudi politične tolerance, spodbujanja in sofinanciranja) in $v$ obliki nacionalno toleriranega življa na obeh straneh. Manjšine v obeh državah, predstavniki obeh nacij tako "tu« kot »tam« in konec koncev tudi notranji umetniški naboji pa so tista vrela, ki so praktično neusahljiva.

\footnotetext{
${ }^{2}$ Ansambel bratov Avsenik je $v$ svetovnem merilu verjetno najuspešnejša slovenska glasbena skupina. Delovala je od leta 1953 do 1990. Skupina je bila sprva trio, ki je kmalu prerasel v kvartet in leta 1955 v Gorenjski kvintet, ta pa se je preimenoval v Kvintet bratov Avsenik: harmonika, kitara kontrabas/evfonij-bariton, klarinet, trobenta, pevski duo in (nazadnje) tercet.

3 Diatonična harmonika, okrajšano DHA, sicer pa tudi gumbna harmonika, pogovorno frajtonar'ca oz. prostotonska harmonika, je vrsta harmonike, za katero je značilno, da pri stiskanju meha na neki tipki proizvaja en ton, pri vlečenju pa drugega, zato diaton.

${ }^{4}$ Guča je mestno naselje v Srbiji, v občini Lučani v Moraviškem upravnem okraju. V Guči se vsako leto odvija tradicionalni Dragačevski festival trobentačev.

${ }^{5}$ Gúsle so ljudsko glasbilo, vrsta enostrunskih godal. Največ se uporabljajo na Balkanskem polotoku in Dinaridih (tj. Dinarske Alpe), predvsem pri nekaterih južnih Slovanih. Na to področje so jih verjetno prinesli iz Azije v 8. ali 9. stoletju.
} 
In medias res: takoj $\mathrm{k}$ bistvu ...

Prvi začetki omenjenega občasnega in nenačrtnega sodelovanja trajajo med Slovenci in Srbi vse od nacionalnih gibanj po letu 1848 oz. 1860. Zavest o tovrstnem sodelovanju na tem južnoslovanskem območju in na področju glasbene dejavnosti ter $v$ tem skupnem geografskem in kulturnem območju nikoli ni bila zelo močna. Pred koncem 1. svetovne vojne, torej pred 1918 sta bili vidni in povezujoči glasbeni osebnosti predvsem S. S. Mokranjac in D. Janko. Ta je panslavistične ideje z Dunaja najprej prinesel v Slovenijo in nato še l. 1862 v Srbijo (najprej v Pančevo). ̌̌e od 1865 je deloval v Beogradu (1870-1902) kot dirigent v tamkajšnjem Narodnem gledališču (Narodnom pozorištu).

Skladatelj in zborovodja Davorin Jenko je bil samouk, avtodidakt. Še kot študent prava je na Dunaju (1858-1862) kot zborovodja vodil Slovensko pevsko društvo, zatem 1863-1865 Srbsko cerkveno pevsko društvo v Pančevu (Srbija), 1865-1877 Beograjsko pevsko društvo, 18711902 pa je bil dirigent v srbskem Narodnem gledališču v Beogradu. Med njegovimi glasbenimi prvenci so vokalne skladbe (zbori in samospevi). Najpopularnejša iz tega Jenkovega opusa je prav gotovo Naprej, zastava slave!, moški zbor a cappella (1860, na besedilo oz. poezijo Simona Jenka), ki je pozneje postala slovenska himna. Panslavističen pa je bil tudi njegov prvi (glasbeni) opus, obe zbirki, op. 4 (1869) in op. 5 (1870) Srpskih, hrvatskih i slovenskih pesama. V tem beograjsko-srbskem okolju je D. Jenko preživel in deloval več kot polovico svojega življenja. Kompozicijsko dejavnost je razširil še na inštrumentalno in scensko. Namreč, napisal je glasbo za več kot 80 iger, mdr.za igre Vračara (1882), ki je predhodnica srbske operete, in za igro Pribislav i Božana (1894), ki pa je že blizu tipu romantične opere. V svoji glasbi je uporabljal tudi elemente srbske ljudske glasbe. Jenko se uvršča med začetnike srbskega nacionalnega sloga, ki ga je utemeljil K. Stanković, realizirala pa sta ga S. Stojanović Mokranjac in J. Marinković. Tako je Jenko pomemben predvsem za razvoj srbske glasbe njenega zgodnjega obdobja in hkrati za razvoj slovenske glasbene romantike. Je pa tudi avtor glasbe za Bože pravde (slovensko Bog pravice), ki je himna republike Srbije. Uglasbil jo je l. 1872 na besedilo Jovana Đorđevića. To je bila prvotno državna himna Kraljevine Srbije, zato poveličuje srbskega kralja (Pavlović 1986). Srbija (dandanes) uporablja rahlo spremenjeno različico, kjer poudarja, da ni več monarhija; spremenjeni so štirje verzi. $V$ treh je »srbski kralj« nadomeščen s »srbskimi deželami, « v eni pa »Bog ohrani srbskega kralja« z »Bog ohrani, bog obrani« (Jenuš in Križnar 2015: 14, 21).

M. Logar (1902-1998) je slovensko-srbski skladatelj, pedagog in publicist. Glasbo je študiral v Pragi pri Josefu Suku. Zaradi fašističnega nasilja se je leta 1927 preselil v Beograd. Tam je do leta 1972 deloval kot profesor kompozicije na Glasbeni akademiji.

Kot skladatelj tradicije je M. Kozina (1907-1966) izpričal izvirnost in svojevrstno življenjsko vitalnost, s čimer si je v slovenski glasbi pri- 
dobil mesto upoštevanja vrednega ustvarjalca. Živel je $\mathrm{v}$ času velikih preizkušenj, v katerem je bil s kompozicijsko usmerjenostjo in političnim prepričanjem blizu povojni oblasti. Bil ji je očitno potreben, zato mu je po vojni omogočila kariero, čeprav kaže, da je bil pozneje razočaran in kritičen do nje. Študiral je na ljubljanskem konservatoriju, na Dunaju pri J. Marxu in na mojstrski šoli praškega konservatorija pri J. Suku, neke vrste vzorniku. Dirigiranje je končal pri N. Malku. V Mariboru je začenjal kot dirigent zbora in orkestra Glasbene matice ter direktor njene šole, poučeval je na glasbeni akademiji v Beogradu (1940-1943, 1945-1947), vmes pa je bil kulturno in glasbeno dejaven $v$ partizanih (Tomašek,1982). Nadaljeval je kot upravnik novoustanovljene SF in profesor na $A G$ v Ljubljani vse do upokojitve.

Hkratno sosledje na slovenski strani pomeni od l.1899 izvedbe Mokranjčevega ciklusa Rukoveti, venčkov srbskih ljudskih pesmi, ki jih je izvajal zbor Glasbene matice Ljubljana (GML) tako doma kot v tujini, po l. 1918 tudi na slavnostnih priložnostih (akademije v spomin na Janeza Evangelista Kreka, 1918; ob 100-letnici smrti Valentina Vodnika, 1919; ob 50-letnici GML, 1922) in na turneji po Češkoslovaški leta 1928. Mokranjčeva dela - rukovete so peli tudi drugi slovenski zbori. Ti so spored srbske zborovske literature razširili še na klasične skladbe Srbov M. Milojevića, P. Konjovića, S. Hristića idr. Po l. 1918 pa so ti slovensko-srbski stiki postali redni in načrtni, vendar ne zaradi resničnega pretoka glasbenih idej ali zanimanja za poustvarjalne dosežke drugih, temveč prej v zvezi z bolj zunajglasbenimi priložnostmi. Pri tem so bili izjema stiki, ki so se med obema vojnama (1918-1941) vzpostavili med glasbeniki, zlasti skladatelji, ki so se sočasno šolali v istih glasbenih središčih v tujini (Praga) in so izhajali is skupnega (panslovanskega) nacionalnega in estetskega izhodišča. Dela srbskih skladateljev (P. Konjović, S. Binički, I. Bajić, K. Manojlović, S. Hristić, Dimitrije »Mita« Topalović, Petar Krstić, P. Stojanović, M. Živković, P. Milošević, D. Radić, Erne Kiraly, Konstantin Babić, Zoran Erić, Dimitrije Golemović idr.) so najbolj pogosto izvajali srbski glasbeniki na gostovanjih po Sloveniji. Mokranjčevi rukoveti pa so bili in so še danes stalno na repertoarju slovenskih zborov. V času skupne države so stike utrjevale tudi izmenjave opernih in baletnih predstav in simfoničnih orkestrov (Enciklopedija Slovenije 1998, 240-41).

\section{... in v sodobnosti do danes}

Od slovenskih skladateljev so v Srbiji od 30-ih let 20. stol. najpogosteje izvajali skladbe Zlatana Vaude (slovensko-srbski skladatelj in pedagog), L. M. Škerjanca, A. Lajovica, E. Adamiča, Antona Foersterja, S. Osterca (njegov Magnificat za mešani zbor in klavir 4-ročno iz leta 1932 je Beograjsko pevsko društvo izvedlo že leta 1936; glej Rijavec 2019),

${ }^{6}$ Prim.Wikipedia, 27.3.2019 in (U.Lajovic): https://www.bgf.rs/It/dirigent:cp/uros-lajovic/. 
po 2. svetovni vojni, ko se je (takratno) medrepubliško sodelovanje institucionaliziralo v okviru Zveze skladateljev Jugoslavije, Jugoslovanske radiodifuzije, Jugoslovanske glasbene tribune v Opatiji (Hrvaška), Festivala Ljubljana (Operni in baletni bienale), Glasbene mladine Jugoslavije idr., pa predvsem dela U. Kreka, M. Kozine, B. Arniča, M. Bravničarja, Lojzeta Lebiča, P. Ramovša, Marijana Gabrijelčiča, Alojza Srebotnjaka, Daneta Daniela Škerla, Jakoba Ježa idr. Gostovanja Filharmonij (Beograjske in Slovenske) z obeh območij, sodelovanje srbskih zborov na tekmovanjih v Sloveniji in slovenskih v Nišu ter na Beograjskih glasbenih svečanostih (BEMUS) so izrabili za spoznavanje skladb iz drugih okolij. Od srbskih poustvarjalcev - (glasbenih) izvajalcev so v Sloveniji nastopali: pevci baritonist N. Cvejić, basista M. Čangalović in M. Jovanović, mezzosopranistka J. Stamatović Nikolić; pianisti J. Dokić Đuraković, E. Indjic, D. Jovanović (v duu z bratom violinistom Milanom), K. Gekić, O. Jovanović, N. Kecman, R. Kinka, A. Madžar, duo Milica in Lazar Marjanović, O. Mihailović (v duu s sestro violinistko Marijo), M. Petrović, J. Stančul, M. Vukdragović, A. Serdar; violinisti J. Kolundžija, S. Milenković, R. Dimitrova, P. Toškov, P. Stojanović, S. Krstić; violončelistka K. Janković; dirigenta Ž. Zdravković in D. Matić Marović (s pevskimi zbori FMU Beograd, Collegium Musicum, Obilić idr.); pevski zbori, Orkester kraljeve garde, Beograjska filharmonija, komorni ansambli in folklorna društva, $A P Z$ ». Krsmanović«, AKUD»B. Krsmanović« idr.

Opera in balet SNG Ljubljana je uprizorila operi P. Konjovića Miloševa ženitev (1927) in Koštano (1931) ter Hristićev balet Ohridska legenda $(1949,1954)$, ki so jo trikrat postavili tudi v SNG Operi in baletu Maribor $(1954,1958,1976)$. Od slovenskih glasbenih poustvarjalcev so po Srbiji in še posebej v Beogradu poleg solistov posameznikov, kot so Aci Bertoncelj / klavir, D. Bravničar, P. Novšak in I. Ozim / violina, A. Dermota / tenor, I. Grafenauer / flavta, J. Gostič / tenor, M. Gregorač, M. Kalin (nov. 2005, 37. BEMUS v Mahlerjevi 3. simfoniji z dirigentom Z. Mehto), gostovali tudi dirigenti, S. Hubad, B. Leskovic, A. Nanut, M. Munih, U. Lajovic (mdr. tudi šef-dirigent Beograjske filharmonije, 2001-2005), M. Mlejnik / violončelo, D. Tomšič Srebotnjak / klavir idr., ter pevski zbori in komorni ansambli, Slovenska filharmonija ter Opera in balet SNG Ljubljana. Poleg D. Jenka so v Srbiji daljši ali krajši čas mdr. delovali slovenske pevke in pevci: A. Čepe, R. Francl, V. Gerlovič, J. Gostič, V. Heybal, J. Križaj, M. Lubej, C. Medved Škerlj, A. Meze, A. Planinšek, Š. Polič, F. Puhar, J. Rijavec, D. Stare, M. Šimenc, pevec in režiser A. Koren; pihalci E. Ačkun, B. Brun, M. Gunzek / klarineti, E. Gotvald / oboa, F. Grassel / flavta, I. Turšič / fagot; J. Pikelj / harfa, Bogomir in Božidar Gorše, U. Prevoršek / violine; I. Brezovšek, F. Klinar, A. Kolar, R. Zakrajšek, N. Žličar / dirigenti, B. Adamič, M. Fajdiga, M. Polič, R. Simoniti, V. Savnik, Z. Vauda / skladatelji in dirigenti, Z. Ciglič, J. Kalčič, I. Rupnik, S. Šuklar / skladatelji in pedagogi, muzikologinja M. Bergamo; v Sloveniji pa Srbi - pevci in pevke N. Cvejić, V. Lacić, D. Ognjanović ter dirigenta O. Danon in A. Spasić. 
$\checkmark$ glasbeni publicistiki je bil med vojnama $v$ beograjskih glasbenih revijah Muzika, Muzički glasnik, Slovenska muzika in Zvuk zelo dejaven S. Osterc kot zagovornik t. i. nove glasbe, polemični pisec in poročevalec iz tujine, saj je bil mdr. predsednik ljubljanske sekcije Udruženja jugoslovenskih muzičkih autora in tudi član odbora Mednarodnega društva za sodobno glasbo SIMC (ISCM), s tem pa posredno tudi član žirij za njihove festivalske programe, kar je nedvomen dokaz o ugledu, ki ga je imel $\checkmark$ mednarodnih glasbenih krogih. Hkrati pa to neposredno dokazuje Osterčevo organizacijsko, skoraj bi lahko rekli diplomatsko sposobnost (Rijavec 1979, 199). Ob Ostercu pa je v Beogradu še največ objavljal A. Lajovic. Po letu 1945 so v revijah Zvuk, Pro musica, Suvremeni akordi idr. objavljali mnogi slovenski glasbeni pisci in muzikologi, predvsem D. Cvetko (ki je bil tudi eden od urednikov Zvuka, Beograd, 1932-36, 1956-67, Sarajevo, 1967-90; izdajatelj in založnik SOKOJ). Razen občasnih objav v slovenskih revijah med vojnama so srbski muzikologi, predvsem tisti, ki so se izpopolnjevali v Ljubljani, s prispevki sodelovali pri Muzikološkem zborniku, nekateri so sodelovali in še sodelujejo na simpozijih Festivala Ljubljana - Slovenski glasbeni dnevi (Ljubljana et al, 1986-34, 2019). Cvetko sam je v Beogradu objavil monografijo o Jenku (Davorin Jenko i njegova doba, SAN, 1952), Ľivot i rad kompozitora Rista Savina (Nolit, 1958), njegovo temeljno delo Južni Sloveni u istoriji evropske muzike (Nolit, 1984) pa je izšlo tudi v srbskem prevodu (Cvetko 1981). Srbsko glasbeno kulturo je še naprej raziskovala M. Bergamo in v Beogradu objavila tri knjige. Očitno se je Cvetkova »ljubljanska muzikološka šola« nadaljevala in oplajala tudi s srbsko, saj so tam delovali številni (prvi) srbski doktorji znanosti s področja muzikologije, ki so si naziv pridobili prav v Ljubljani (N. Mosusova, R. Pejović, D. Petrović idr.). Po letu 1991 se je institucionalno sodelovanje pretrgalo, ostale pa so še pobude posameznikov.

\section{Balet}

Tudi na baletnem področju, ki je morda glasbi najbližje, je bilo tako. Še najbolj se je bilateralno sodelovanje med Slovenijo in Srbijo tako na glasbenem kot tudi na baletnem področju intenziviralo po koncu 1. svetovne vojne. Po odhodu ruske baletne pedagoginje J. Poljakove iz Ljubljane so nekateri slovenski plesalci študirali pri njej v Beogradu in obenem več sezon plesali $v$ beograjskem Narodnem gledališču: $\mathrm{S}$. Eržen, B. Pilato, Š. Suhi, Pia in Pino Mlakar. L. Wisiak, V. Vlček in zakonca Mlakar so imeli tam svoje solistične nastope. Mlakarja sta v Beogradu tudi koreografirala. » $\vee$ zameno pa so večkrat v Ljubljani gostovali vodilni plesalci-solisti ruskega rodu iz Beograda. Po 2. svetovni vojni so bili ti plesni in baletni stiki tesnejši in bolj načrtni, saj so $v$ obeh smereh gostovali baletni ansambli iz Beograda, Novega Sada, Ljubljane in Kopra. V Ljubljani enkrat, vendar s številnimi ponovitvami, in trikrat v 
Mariboru (leta 1958 samo 4. dejanje) so postavili Hristićev balet Ohridska legenda. Precej je bilo obojestranskih gostovanj posameznikov, baletnih solistov. V Sloveniji so kot plesalci mdr. nastopili J. Bjegojević, Mile Jovanović in D. Trninić, kot koreografi Mile Jovanović, V. Kostić, K. Obradović in D. Parlić, kot scenografa in kostumografa pa še D. Ristić in M. Tabački. Več srbskih plesalk je bilo dalj časa vključenih v ljubljanski ali mariborski Baletni ansambel SNG: O. Ilić, L. Keča idr. Od Slovencev so v Srbiji gostovali predvsem koreografi. $\vee$ tem je velik prispevek I. Otrina, ki je bil v letih 1965-71 in 1991 celo vodja novosadskega Baleta. Tam je postavil 16 baletov (Šeherezada), zakonca Mlakar sta v Beogradu koreografirala še trikrat (Ohridska legenda, 1978), H. Neubauer pa je v Novem Sadu leta 1973 postavil balet Otelo - Mletački crnac (Beneški črnec). Vsi ti stiki so predvsem koreografsko in scenografsko obogatili repertoarje sodelujočih gledališče in seveda posredno tudi Slovencev in Srbov (Enciklopedija Slovenije 1998, 241).

\section{Najnovejši stiki po 1991 ...}

V zadnjih desetletjih je pomembno vlogo odigral tudi Jugokoncert (ustanovljen 1946., ukinjen 2014. leta), nazadnje kot mestni (beograjski javni zavod) ustanovitelj, soustanovitelj ali izvršni producent niza pomembnih (glasbenih) festivalov in drugih projektov, kot so: Beogradske muzičke svečanosti (BEMUS) in Mednarodna tribuna skladateljev (1991 $\rightarrow),{ }^{7}$ Čelo fest, Pijanistička fešta, Mednarodni festival harfe ...8 Aktualno je bila $v$ Beogradu prisotna tudi slovenska zabavna glasbena scena. Tako je npr. 15. decembra 2005 v beograjskem Centru Sava gostoval sloviti in reprezentativni ansambel Laibach. ${ }^{9}$ Obstajajo celo primeri osnovnošolskega sodelovanja. Tako je Učiteljski ženski pevski zbor OŠ Naklo z zborovodjem M. Kavčičem in pianistko M. Ovsenik 9. decembra 2005 gostoval v Beogradu, v katedralni cerkvi Blažene Djevice Marije. ${ }^{10}$ Na sporedu so bila svetovna in slovenska zborovska dela, izvirniki in priredbe za ženski zbor (a cappella in s klavirjem). APZ »T. Tomšiča« s takratno zborovodkinjo U. Lah je imel 4. julija 2006 koncert v beograjski katedralni cerkvi Blažene Djevice Marije. ${ }^{11} \mathrm{Na}$ tem sporedu so bila zborovska dela s svetovne in slovenske glasbene scene. Skupni nastop solistov, zborov in recitatorjev pa so pripravila društva Slovencev iz Su-

\footnotetext{
${ }^{7}$ V organizaciji Udruženja kompozitora Srbije.

${ }^{8}$ Prim. Wikipedia (27. 3. 2019).

${ }^{9}$ Laibach je slovenska glasbena in večmedijska skupina, ki se poleg glasbe izraža še s pomočjo oblikovanja, slikarstva, gledališča in ostalih umetniških praks.

10 Prim. koncertni list Urada Vlade RS za Slovence po svetu, Ljubljana, in Društva Slovencev "Sava«, Beograd (elektr. pismo Jurija Devetaka iz Beograda F. Križnarju, 23. 12. 2005; hrani avtor).

${ }^{11}$ Prim. koncertni list in elektr. pismo Jurija Devetaka F. Križnarju (5. 7. 2016; hrani avtor).
} 
botice, Zrenjanina, Beograda, Niša, Vršca in Novega Sada v novosadski Sinagogi, 17. novembra 2006. Na njihovi 4. tovrstni prireditvi - koncertu slovenskih pesmi in poezije je bilo slišati večinoma slovensko glasbo in poezijo. ${ }^{12}$ Reden ali vsaj občasen gost beograjske glasbene scene je mdr. tudi sloviti Slovenski oktet. ${ }^{13}$ Ta je najprej nastopil leta 2003 v atriju beograjskega Narodnega muzeja, potem pa še 3. novembra 2007 $v$ tamkajšnji katedralni cerkvi Blažene Djevice Marije. Tudi beograjska muzikologinja D. Petrović, ki je prav tako doktorirala v »ljubljanski muzikološki šoli« akademika D. Cvetka, je na predavanju v okviru Vidovdanskega večera (Društvo Srbska skupnost v Sloveniji in MI SANU, Ljubljana, Mesti muzej, 27. jun. 2007) z naslovom Sloji glasbenih kultur na Balkanu zagotovo stkala pomembne srbsko-slovenske glasbene vezi. ${ }^{14}$

V letih 2001-2005 je bila v okvirih izmenjav med Slovenijo in Srbijo zelo dejavna Glasbena mladina Vojvodine. V tem času so s slovenske strani tam gostovali violončelist A. Petrač (z zagrebškim pianistom V. Krpanom), Slovenski trobilni kvintet, violončelist M. Mlejnik z njihovo pianistko R. Kinko, Beograjska filharmonija s solisti, zborom »Koče Kolarova« iz Zrenjanina in našim dirigentom U. Lajovicem, Kvartet Tartini z njihovim pianistom D. Leljakom, srbskim klarinetistom N. Srdićem in hrvaškim pianistom L. Pogorelićem, Madžarski virtuozi z našo violinistko L. Trotovšek, naša pianistka T. Ognjanović, harmonikar E. Sebastijan, kantavtor Z. Predin, sam in s »svojimi« Malimi bogovi, organist D. Miklavčič, naš klarinetist D. Brlek s Kvartetom Kodaly, Mešani zbor Obala iz Kopra z dirigentom A. Čopijem, dva tria flavt: In vivo in Sonček, naša violinistka K. Šuklar s hrvaško pianistko N. Majnarić, Simfonični orkester RTV Slovenija z angleškim dirigentom S. Edwardsom in našim hornistom B. Lipovškom, umetniški performans Bertalanič, Z. Bogdan in Tamburaški orkester Radia Novi Sad (gostovanje v Murski Soboti), pevka N. Vipotnik, harmonikar Z. Štih z večerom šansonov idr. Večina teh koncertov je bila izvedenih na Novosadskim muzičkim susretima, Novosadskom muzičkom letu, Festivalu akustičarjev, Podiju mladih idr.; največkrat v novosadski Sinagogi. ${ }^{15}$

V času 2002-2004 so po podatkih Ministrstva za zunanje zadeve $R S^{16}$ učenci OŠ »F. Prešerna« iz Kranja sodelovali v Beogradu na festi-

\footnotetext{
12 Prim. koncertni list Društva Slovencev »Kredarica«, Novi Sad.

${ }^{13}$ Prim. koncertni list Urada Vlade RS za Slovence po svetu, Ljubljana in Društva Slovenaca "Sava«, Beograd (elektr. pismo Jurija Devetaka iz Beograda F. Križnarju, 6. 11. 2007; hrani avtor).

${ }^{14}$ Prim. inf. cit. Društva v Sloveniji.

15 Prim. popis Milana Radulovića (Muzička omladina Novi Sad; elektr. pismo F. Križnarju, 23.11. 2005; hrani avtor).

${ }^{16}$ Neformalni sestanek, 16. 12. 2005, ki sem ga imel z enim od uradnikov MZZ, Sektor za mednarodne odnose $v$ kulturi.
} 
valu Radost Evrope (Otroški kulturni center Beograd, 2002); Beograjska filharmonija je s takratnim glavnim dirigentom U. Lajovicem igrala $\mathrm{V}$ Avditoriju Portorož v okviru takratnih jubilejnih 80. Svetovnih glasbenih dnevov, 27. 9. 2003; Orkester Slovenske filharmonije je igral oz. gostoval na BEMUS-u (25. 10. 2003 v Centru »Sava»); bogato pa je bilo tudi leto 2004: od januarja do maja so v Novem Sadu gostovali: Mariborski oktet, pianistka D. Tomšič Srebotnjak s Komornim godalnim orkestrom Slovenske filharmonije in Kvartet Tartini (vsi v tamkajšnji Sinagogi). V Ljubljani je bil 28. 6. 2004 ustanovljen Forum Slovanskih kultur s članico R. Srbijo. Na ljubljanskem Poletnem festivalu (28. 7. 2004) je gostoval Zbor FMU iz Beograda, na Guitar Art Festival v Beogradu je igral kitarist T. Rajterič, istega leta (novembra 2004) pa še na 13. festivalu sodobne glasbe v Beogradu Trio »Slavko Osterc«: N. Prešiček / klavir, L. Hawlina Prešiček / flavta in D. Prešiček / saksofon.

$\mathrm{Na}$ Beogradskim muzičkim svečanostima (BEMUS), vsakoletnem mednarodnem glasbenem festivalu (ust. 1969), so v Beogradu v zadnjih letih nastopili trije ugledni in mednarodno afirmirani slovenski umetniki solisti: pianistka D. Tomšič Srebotnjak, flavtistka I. Grafenauer in klarinetist M. Bekavac. ${ }^{17}$

D. Jenku kot skladatelju in dirigentu posvečajo $v$ Beogradu toliko pozornosti kot nikjer drugje, razen morda še $v$ njegovih slovenskih Dvorjah oz. Cerkljah (na Gorenjskem). V Beogradu so leta 1954 ustanovili (osnovno) glasbeno šolo (na podlagi predhodnih tečajev, leta 1951) in jo poimenovali prav po Davorinu Jenku. Ta je dandanes (od 2000 dalje) prerasla v srednjo glasbeno šolo. Prav tam pa so ustanovili še Mednarodno glasbeno tekmovanje, prav tako poimenovano po Jenku, ki je aktualno še dandanes.

V organizaciji ali na povabilo katoliške cerkve v Beogradu (župnije in škofije) so v njihovi cerkvi (Blažene Djevice Marije in drugod) ali/in zunaj nje med drugimi nastopili še naslednji slovenski izvajalci: ljubljanska folklorna skupina COF (»Društvo optimistov« v svečani dvorani Kulturno umetniškega društva Lola/Ivo Lola Ribar), Pihalni orkester "Krka« iz Novega mesta (v dvorani Studentskog kulturnog centra/SKC), ${ }^{18}$ Slovenski oktet, Mešani pevski zbor »/van Cankar« iz Logatca-Vrhnike, Me$P Z$ »Revoz« iz Novega mesta z zborovodkinjo C. Kampelj in pianistko A. Dreo, MePZ »Obala« iz Kopra (na »mini« turneji: Kragujevac-BeogradNovi Sad), ŽePZ »asmin« iz Novega mesta z zborovodkinjo M. Dobovšek, MoZ iz Pivke z zborovodjem M. Štefančičem, dva slovenska zbora iz Novega Sada pa sta v njihovi organizaciji nastopila tudi v Beogradu. ${ }^{19}$

\footnotetext{
17 Inf. s 37. festivala BEMUS, prim. Wikipedia, 9. 12. 2005.

${ }^{18}$ Marsikatero gostovanje je potekalo v organizaciji Društva Slovencev »Sava« iz Beograd (prim. Bilteni Društva Slovencev »Sava«).

${ }^{19}$ Prim. korespondenco oz. elektronska pisma z beograjsko Nadškofijo, Jurijem Devetakom in Anico Sabo iz Beograda (20.10. do 13.11. 2005; pisma hrani avtor).
} 
Enega zadnjih tovrstnih (bilateralnih) dosežkov predstavlja festival BG-U EXPRESS, v okviru katerega sta 11. 9.2005 v Viteški dvorani ljubljanskih Križank v mladem klavirskem duu S. Lončar in A. Pavlović nastopila z deli evropskih in srbskih skladateljev. ${ }^{20}$

23.-25. novembra 2017 je v Beogradu na Tribuni o filmski glasbi v okviru Dnevov slovenskega filma gostoval naš glasbeni strokovnjak za področje filmske glasbe, cineast, skladatelj, pianist in esejist doc. dr. M. Reichenberg. 31. maja 2018 je v Beogradu v Domu vojske Srbije gostoval naš klarinetist-solist A. Zupan z dirigentom P. Medakovićem, s koncertantnimi deli srbskih skladateljev D. Lazića in V. Peričića in umetniškim ansamblom Ministrstva za obrambo "Stanislav Binički«. ${ }^{21}$ 29. marca 2019 je v Beogradu, potem pa še $v$ njihovi svečani dvorani nastopal Pihalni orkester KGBL s solistom-pozavnistom M. Štihom, pod vodstvom A. Zupana. ${ }^{22}$

Današnji dogodki, pa tudi srbske glasbene, plesne, baletne in folklorne prireditve se po Sloveniji v glavnem odvijajo pod okriljem Zveze Nacionalni svet Srbov Slovenije in Saveza srpskih društava Slovenije. Obe organizaciji združujeta več kot 10 tovrstnih društev po Sloveniji. V R. Srbiji je to Nacionalni svet Slovencev, ki prav tako deluje po celi državi in tudi izven nje (Bosna in Hercegovina). Zraven pa so še številni uradi in ministrstva, društva, JSKDRS, torej obe »uradni« državni politiki (Slovenije in Srbije), posamezniki in civilna društva (združenja).

Med diskografijo in preostalim (glasbenim) tiskom, festivali, bogatim (glasbenim) ljubiteljstvom in profesijo je treba omeniti tako cerkveno kot posvetno glasbo. Za prvo lahko zapišemo, da jo v smislu medreligijskega povezovanja in različnosti ter posamičnosti omogočajo tudi (krščanska) Cerkev, Evangeličani in Pravoslavci ter še kdo, tako na slovenski kot srbski strani. Povezovanje poteka v smislu medreligijskega in medkulturnega, še posebej medglasbenega dialoga, in to navzlic temu, da se je Slovenija v začetku 90 -ih let (po 1991) ločila od Balkana in s tem posredno tudi od Srbije ter po skoraj 80-ih letih skupnega življa od lucidno poimenovane »balkanske krčme «²3, k kateri je bila kljub izpričani prilagodljivosti vendarle tujek.

\section{Zaključek}

Če so bili že začetki tega slovensko-srbskega glasbenega sodelovanja v več kot 200-letnem razvoju izjemno bogati in raznoliki, saj je tudi

\footnotetext{
${ }^{20}$ Prim. program in elektronsko pismo Bora Turela F. Križnarju (7. 9. 2005; hrani avtor).

21 Inf. na spletu www.ansambel.mod.gov.rs/lat/42/klarinetu-s-ljubavlju-42 (1. 4. 2019), prim. elektronsko pismo H. Milošević UA MO STANISLAV BINIČKI F. Križnarju (1. 4. 2019; hrani avtor).

22 Prim. elektronsko pismo Andreja Zupana F. Križnarju (31. 3. 2019; hrani avtor).

${ }^{23}$ Krleža Miroslav (1893-1981), hrvaški pisatelj, pesnik in dramatik.
} 
(severni) del Srbije pripadal avstroogrski monarhiji in so takrat Slovenci in Srbi (delno) živeli v isti državi, se je v nadaljevanju tega razvoja sodelovanje odvijalo povsem različno: od intenzivnega sodelovanja, ki so ga tu in tam omogočale ali celo pogojevale politične razmere (skupne države), pa vse do naključnih posamičnosti (po l. 1991). Vsekakor je šlo vseskozi za dokaj enovit slovanski nacionalni prostor, ki pa mu geografska oddaljenost niti ni bila ne vem kako naklonjena. Vsekakor sta mu bila v vsem tem času mnogo bolj naklonjena bližnji Dunaj in Zagreb, kar jima je bilo z malce oddaljenejšo Prago skupno.

Davorina Jenka pri tem ne moremo spregledati. Bil je tisti vezni člen med Slovenijo in Srbijo, ki drži še dandanes: ustvarjalno, poustvarjalno in pedagoško. Enako pomemben je za razvoj začetka srbske (gledališke) glasbe kot za slovensko glasbeno romantiko. Če med množico gostujočih skladateljev kar nadaljujemo, ne moremo mimo Mihovila Logarja, Marjana Kozine, Zlatana Vaude in še koga. Poleg ustvarjalcev pa je tu še cela vrsta pevk in pevcev, (glasbenih) dirigentov ter instrumentalistov, tako Slovencev, ki so gostovali v Srbiji, še posebej v Beogradu, kot Srbov, ki so gostovali v Sloveniji, še posebej v Ljubljani. To intenzivno sodelovanje je bilo še najmočnejše med obema vojnama in po 2. svetovni vojni, po letu 1945, ko sta tudi »uradni« politiki obeh držav (in republik) naravnost spodbujali in načrtno sofinancirali omenjeno sodelovanje; seveda ne samo na glasbenem področju, ampak tako rekoč na vseh področjih družbenega in gospodarskega, političnega in kulturnega življenja. Po letu 1991, ko je prišlo do dveh samostojnih držav, te načrtnosti in množičnosti ni več, čeprav sodelovanje še vedno obstaja. Pojavljajo se številna (glasbena) imena in pa ansambli, ki tako sodelovanje še vzdržujejo, v večini primerov pa gre za izmenjave. Glasbi se povsem enakovredno pridružuje še balet, tj. umetniški ples. Še dandanes lahko pišemo o poglobljenem tovrstnem sodelovanju, ki pa ga je (samo po številu, in ne po kvaliteti) relativno manj. Tako je na področju profesionalne, institucionalne in druge glasbene umetnosti, na področju ljubiteljstva oz. amaterizma, pa tudi na cerkvenem področju, namreč poleg že posebej izpostavljene poklicne izmenjave. Takšna povezovanja so se in se še danes dogajajo na področju (glasbene) umetnosti, pedagogike in znanosti.

\section{Literatura}

Cvetko, Dragotin. 1981. Južni Slovani v zgodovini evropske glasbe. Maribor: Obzorja.

Enciklopedija Slovenije.Zv.12.1998. Slovenska n-Sz. Ljubljana: Mladinska knjiga. Jenuš, Gregor in Križnar, Franc (ur.). 2015. Davorin Jenko 1835-1914. Zbornik simpozija. Ljubljana: Arhiv Republike Slovenije ; Beograd: Arhiv Srbije. 
Jugoslovenska muzika. 1972. U Muzička umetnost: enciklopedijski leksikon Mozaik znanja, tom 12, ur. Dušan Plavša, 230-234. Beograd: Interpres.

Muzička enciklopedija. Knj. 3. 1977. Or-Ž (Dodatak). Zagreb: Jugoslavenski leksikografski zavod.

Pavlović, Milivoje. 1986. Knjiga o himni. Jugoslovenski narodi o himni i himna među narodima. Beograd: Nova knjiga.

Rauch, Tomaž. 2016. »Slovenska ljudska glasba: takšna in drugačna«. V Drugačnost $v$ slovenskem jeziku, literaturi in kulturi: zbornik predavanj 52. SSJLK, ur. Alojzija Zupan Sosič, 87-93. Ljubljana: Znanstvena založba Filozofske fakultete.

Rijavec, Andrej. 1979. Slovenska glasbena dela. Ljubljana: Državna založba Slovenije.

Tomašek, Andrija (ur.). 1982. Muzika i muzičari u NOB: zbornik. Beograd: Savez organizacija kompozitora Jugoslavije (etc).

Franc Križnar

Univerzitet u Mariboru

Centar za interdisciplinarna i multidisciplinarna

istraživanja i studije

Institut muzičkoinformacionih nauka

Slovenija

\section{SLOVENAČKO-SRPSKI KULTURNI I, POSEBNO, MUZIČKI ODNOSI MUZIKA JE BEZGRANIČNA!}

Muzička umetnost je više nego univerzalna, pa danas na toj relaciji postoje samo državne granice, koje vekovima ranije uopšte nisu postojale. Možda su upravo zato u prvom planu specifični, još samo nacionalni (narodni) elementi i današanji aktuelni (muzički) modernizam.

Kroz više nego dvestagodišnji razvoj, muzički odnosi između Slovenije i Srbije ostaju bogati i raznoliki. Dugo su ih uslovljavale zajednička politička situacija i država (Austrougarska monarhija, Država SHS, Kraljevina Jugoslavija, FNRJ i SFRJ). Između oba velika rata, a posebno nakon Drugog svetskog rata, međusobna saradnja bila je intenzivna, dok se kasnije, nakon 1991. godine, razvodnila u slučajnost i pojedinačnost, iako neki oblici saradnje postoje još i danas, pre svega na nivou bilaterale, tj. dvostranih odnosa. Međutim, kroz istoriju postoji prilično jedinstven slovenski nacionalni prostor, u kojem, sa gledišta stvaralaštva, nije moguće prevideti Davorina Jenka. On je bio ta karika između Slovenije i Srbije koja nas spaja još i danas - svojim stvaralaštvom, njegovim obradama i izvedbama, kao i pedagogijom. U mnoštvu gostujućih kompozitora, stvaralaca, interpretatora i izvođača, pevačica i pevača, dirigenata i instrumentalista, kako Slovenaca tako i Srba, takođe ne 
možemo zaobići Mihovila Logara, Marjana Kozinu i Zlatana Vaudu. Ovo istraživanje bavi se bogatim međunacionalnim razmenama, što, takođe, obuhvata i balet. Radi se o sasvim drugačijoj i raznolikoj saradnji, koja je danas sve neuobičajenija - o saradnji u oblasti (muzičke) umetnosti, pedagogije i nauke.

Ključne reči: bilaterala, Jenko, Logar, Kozina, Vauda

\author{
Franc Križnar \\ University of Maribor \\ Center for Interdisciplinary and \\ Multidisciplinary Research and Studies \\ Institute of Music Information Sciences \\ Slovenija
}

\title{
CULTURAL RELATIONS BETWEEN SERBIA AND SLOVENIA, WITH SPECIAL REFERENCE TO MUSIC MUSIC IS BOUNDLESS!
}

The art of music is so ultimately universal that today there are only national borders, which never existed in the past, for centuries. Perhaps this is the reason why vernacular (folk) elements and the current (musical) modernism are in the focus.

Over more than two centuries, the musical relations between Slovenia and Serbia have remained vivid and diversified. For long, they were determined by a shared political situation and the state (Austro-Hungarian monarchy, Kingdom of Serbs, Croats and Slovenes, Kingdom of Yugoslavia, Federal People's Republic of Yugoslavia and the Socialist Federal Republic of Yugoslavia). Between the two great wars, and especially after World War II, the collaboration was intensive. Later, after 1991, it has degraded, becoming merely coincidental and individual, although some forms of collaboration have persisted until this day, primarily at the bilateral level. Nevertheless, throughout history there has existed a rather unified Slavic national space, where, in terms of creative outputs, one must not overlook the contribution of Davorin Jenko. He was a link between Slovenia and Serbia, and he still connects the two countries - through his works, their interpretations and performances, and educational activities. Among many guest composers, the creators of original works and performers, singers, conductors and instrumentalists, both Slovenian and Serbian, the outstanding figures include Mihovil Logar, Marjan Kozina and Zlatan Vauda. This study covers a vivid international exchange, which also includes ballet. Some forms of collaboration are rather different and diverse, which is increasingly uncommon today, and they include the collaboration in the area of art (of music), education and scholarship.

Keywords: bilateral collaboration, Jenko, Logar, Kozina, Vauda 


\section{F. Križnar}

Slovensko srbski kulturni in še...

\section{Hymna strbská.}

Onam, onamo
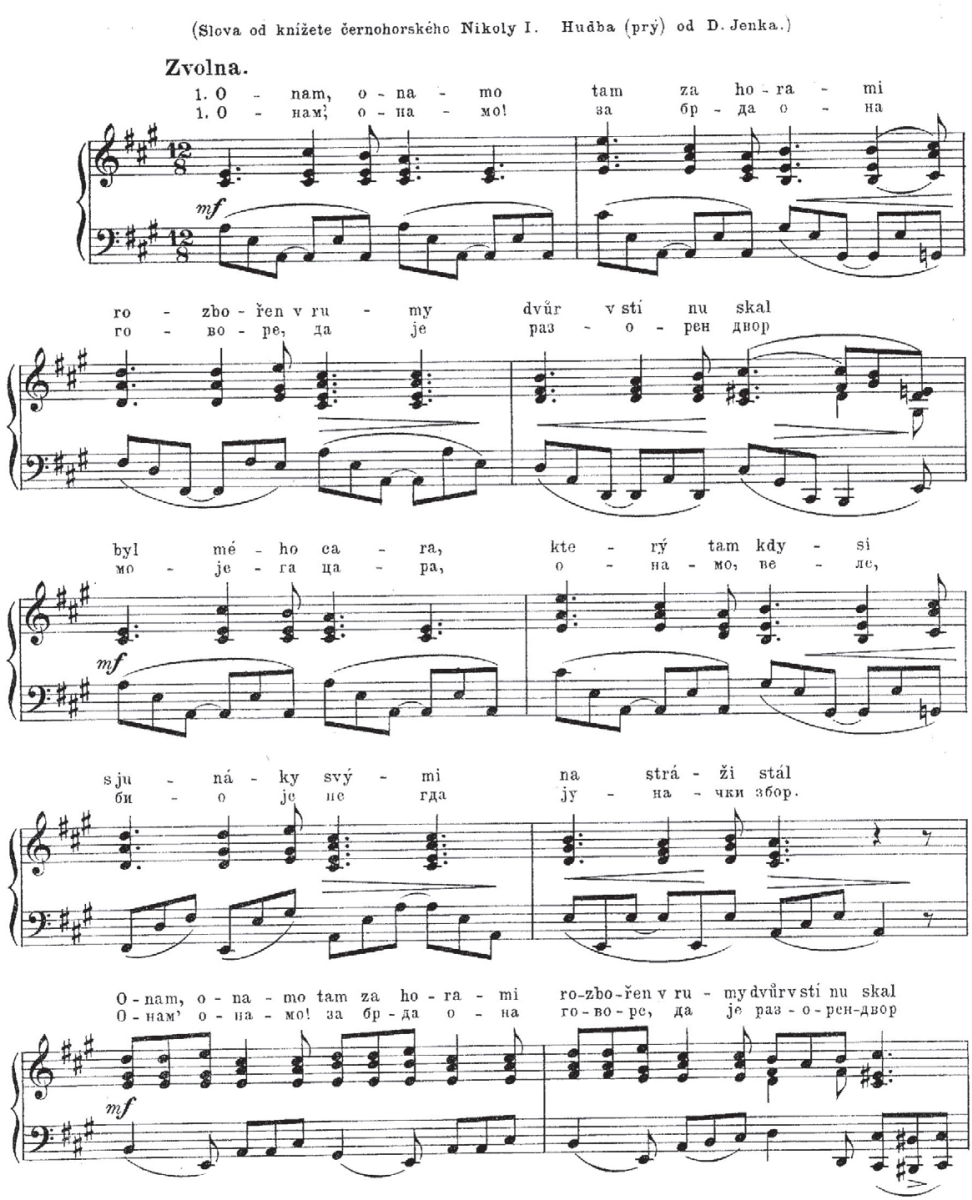

F. Ch. 32

Slika 1a - Hymna srbska (Onam, onamo; glasba D. Jenko; v: Jos. Jeniček, Slovanske hymny /za klavir s podloženim tekstom/, Praga 1900, str. 8 /začetek/; orig. hrani GZ NUK v Ljubljani) 
Srbska:

10. Bože pravde.

(Besedilo Jovana Ď̌ordžríća, glasba Davorina Jenka.)
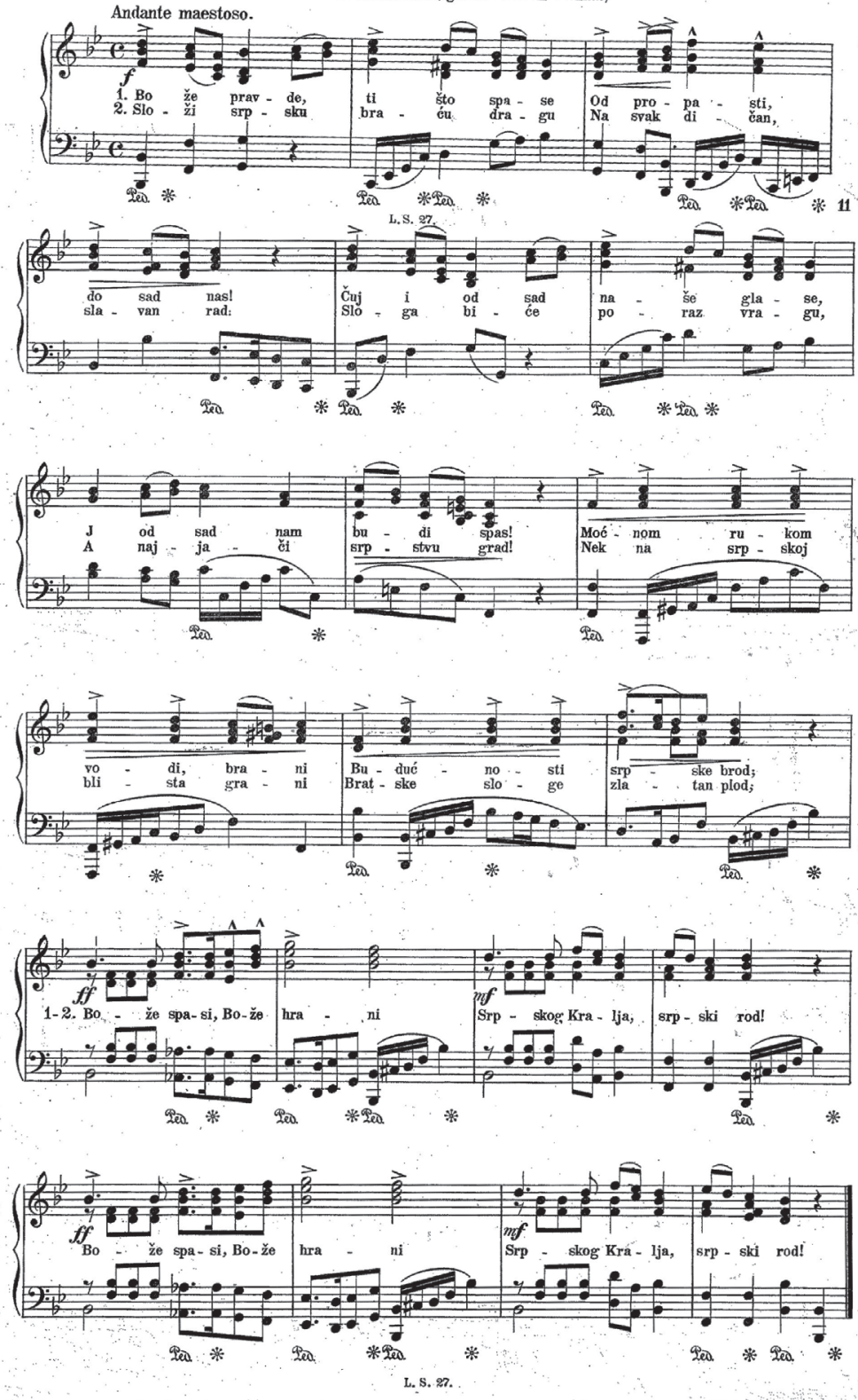

Slika 1b - Bože pravde (bes. J. Džordžević, glasba D. Jenko; v: Fran Gerbič, Slovanske himne/Hymnes Slaves. Ljubljana: L. Schwentner, 1907, str. 8, začetek) 


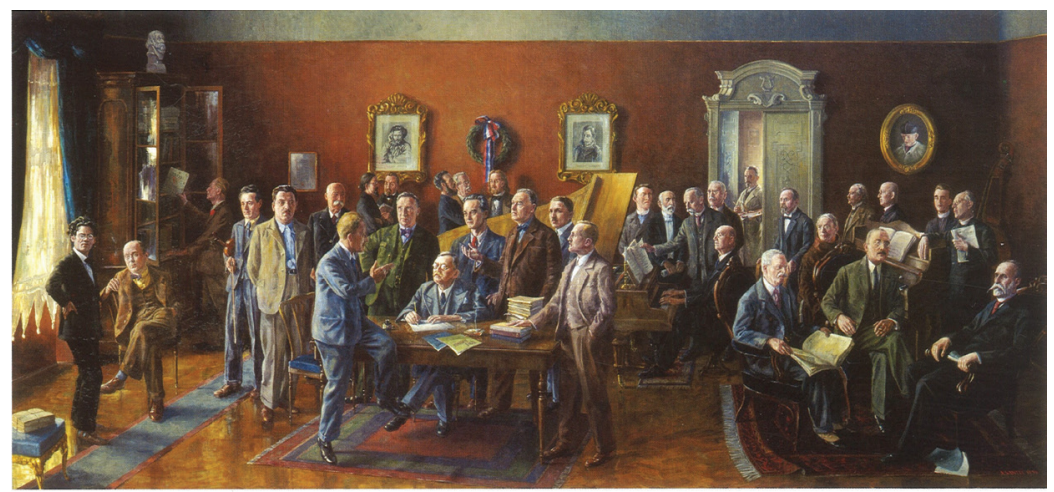

Slika 2a - Saša Šantel, Slovenski skladatelji/Koncil slovenske glasbe, olje, 1936 (z D. Jenkom v ozadju)

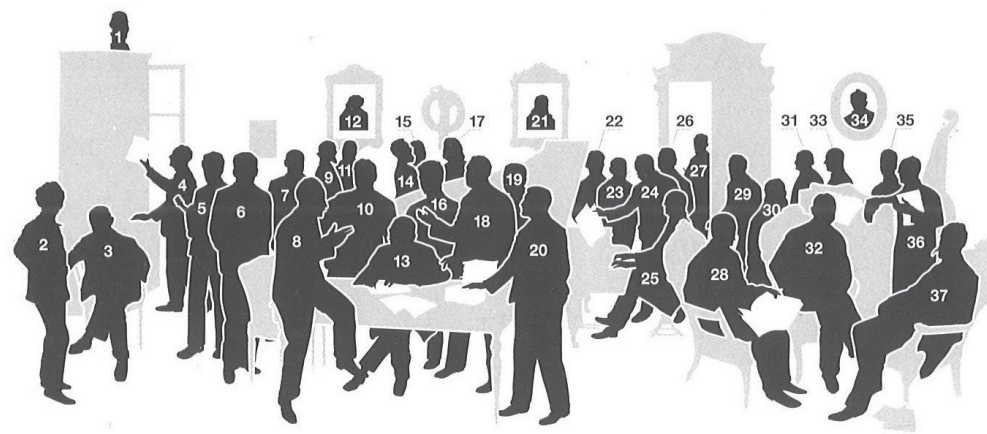

Slika 2b - Legenda zgornje slike (S. Šantel, 1936): D. Jenko je označen s št. 23 (oboje Zgibanka. Ljubljana: Glasbena matica, 2006)

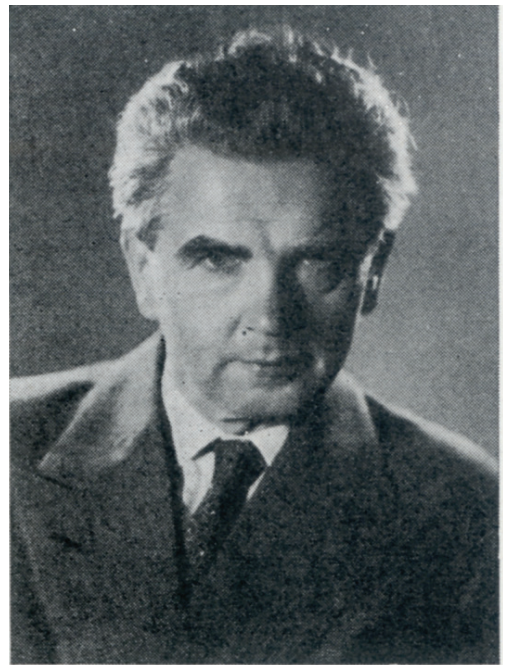

Slika 3 - Mihovil Logar (Reka, 1902 - Beograd, 1998)

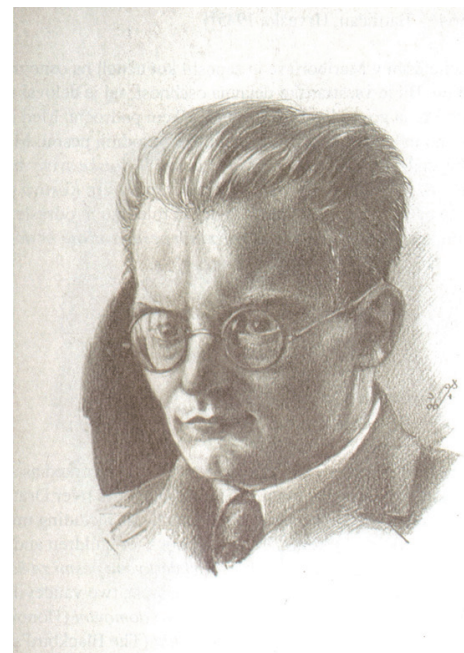

Slika 4 - Marjan Kozina (Novo mesto, 1907 - 1966; v Beogradu: 1940-43 in 1945-47, risba-lesorez Saša Šantel, pred 1936) 


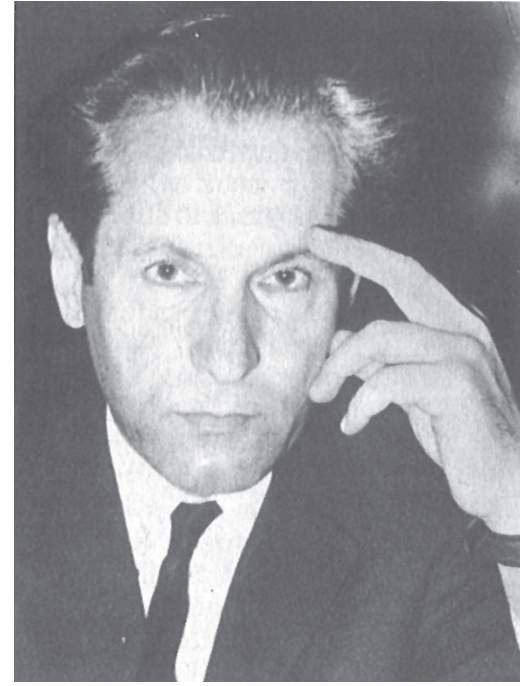

Slika 5 - Zlatan Vauda (Šmarjeta pri Mariboru, 1923 - Beograd, 2010)

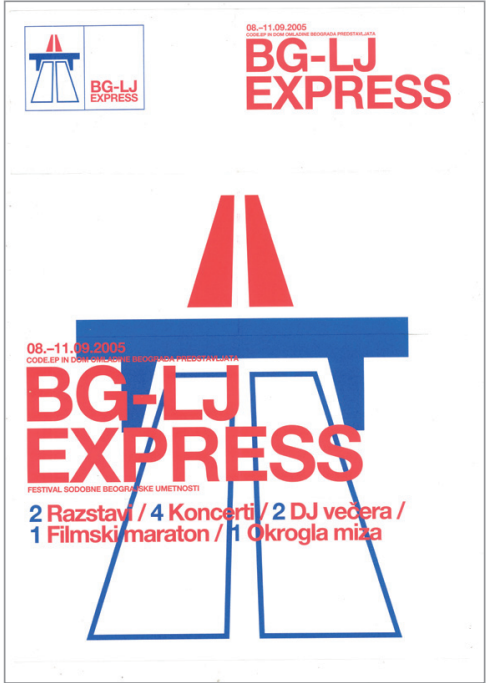

Slika 6 - BG-L EXPRESS (letak-koncertni list, Beograd-Ljubljana, 8.-11. 9. 2005) 